\title{
Organizasyonel Öğrenme, Adımları ve Uygulanması a
}

\author{
Ufuk Saka $^{\mathrm{b}, \mathrm{c}}$, Dr. Cemil Ceylan ${ }^{\mathrm{d}}$
}

\section{Özet}

Organizasyonel öğrenme tartışmalarının tarihine karşın bu başlık yirminci yüzyılın son yirmi yılında bu başlık yeniden doğdu. Organizasyon etkinliğinin niteliği ve öğrenmenin niteliği son yıllarda dikkat çeken başlıklar oldu. Günümüzde organizasyonel öğrenme sertleşen rekabetin ve beklenmedik belirsizliklerin olağanlaştığı piyasalarda şirketlerin başarı yolculuklarında önemli bir yetenek olarak ilgi ve dikkat çekiyor. Böyle olunca da organizasyonel öğrenme başlıklı çalışmalar konuya dikkat çekerken, organizasyonel öğrenme, değişim yönetiminin de çok önemli başlıklarından biri haline geldi. Konuyla ilgili çalışmalar, organizasyonel öğrenme sürecinin farklı adım ya da adımlarına kendi bağlamları itibarıyla işaret ediyor. Çalışmamız, kapsamlı bir kaynak çalışması üzerinden, organizasyonel öğrenme sürecinin adımlarını bir arada görünür hale getirmeyi amaçlıyor ve bu adımların nasıl uygulanacağına dair bir öneri sunuyor.
Anahtar Kelimeler

Organizasyonel Öğrenme

Organizasyonel Öğrenme

Sürecinin Adımları

Organizasyonel Öğrenme

Sürecinin Uygulanması

Makale Hakkında

Geliş Tarihi: 14.10.2019

Kabul Tarihi: 20.11.2019

Doi: 10.18026/cbayarsos.632768

\section{Organisational Learning, Its Steps and Application}

\begin{abstract}
Despite the history of organizational learning discussions, this topic was born again during the last two decades of twentieth century. The quality of organizational efficiency and the quality of learning quality became popular. Today, in the markets where tragically hardening competition and unexpected uncertinities are getting usual, organizational learning attracts attention and care as a major ability in the success voyage of the companies. So, the studies with the topic of organizational learning has attracted attention to the subject and organizational learning has become one of the very important topics of the change management. Studies about the topic indicating different step or steps of organizational learning within their own context. Referring an extensive literature study, our study aims to bring out the steps of organizational learning process altogether and to propose a way on how to apply them.
\end{abstract}

Keywords

Organisational Learning

Steps of Organisational Process

Applying the Steps of

Organisational Learning Process

\begin{aligned} About Article \\ \hline Received: 14.10 .2019 \\ Accepted: 20.11 .2019\end{aligned}

Doi: $10.18026 /$ cbayarsos.632768

a Çalışma Ufuk Saka'nın Doktora Tezi esas alınarak, tez sürecinin tamamlayanı olarak hazırlanmış olup, herhangi bir sempozyumda/ konferansta bildiri olarak sunulmamış ya da bir proje/kurum tarafından desteklenmemiştir.

b İletişim yazarı : Ufuk Saka ufuksaka@gmail.com

c Ufuk Saka Endüstri Yük. Müh. İ.T.Ü. Endüstri Mühendisliği, Doktora Öğrencisi (0000-0003-1168-050X)

d Dr. Cemil Ceylan, İ.T.Ü. Endüstri Mühendisliği, Doktor Öğretim Üyesi (0000-0001-9353-0235) 


\section{Giriş}

Değişimin sürekliliği ve kaçınılmazlığı antik çağlardan bu yana insanlığın hep gündemindeydi. Tarih planında önce üretim biçimlerinde ardından da üretim ilişkilerinde ortaya çıkan değişimler hayatın bütün öteki alanları gibi üretim sistemlerini, bir başka deyişle üretim amaçlı örgütlenmeleri (organizasyonları) de "sürekli ve kaçınılmaz" olarak etkiledi. Yirminci yüzyılın ikinci yarısından başlayarak üretim ve bilgi teknolojilerinin küresel finans süreçlerinin ve rekabetin alabildiğine karmaşıklaşması her nevi üretim organizasyonunda "değişim"i bir yönetim alanı olarak ortaya çıkardı. Bunun ardından pek çok araştırmacı yönetici ve yönetim bilimcinin kimi operasyonel, kimi akademik pek çok katkılarına konu oldu.

Bunlardan biri olarak Peter Senge'nin ilk baskısını 1993'de yaptığı, genişletilmiş 16ncı baskısını 2013 yılında yayınladığı "Beşinci Disiplin / Öğrenen Organizasyon sanatı ve Uygulaması" kitabında önerdiği yaklaşım ve model hem önemli tartışmaların hem de önemli çalışmaların esin kaynağı oldu.

Organizasyonel öğrenme sertleşen rekabetin ve beklenmedik belirsizliklerin olağanlaştığ piyasalarda şirketlerin başarı yolculuklarından önemli bir yetenek olarak ilgi ve dikkat çekiyor. Gerek doğrudan üretimde gerekse pazarlama, finansman, satın alma ve bütün yönetim alanlarında mucize değilse de yol açıcı bir değişim vaad ediyor.

Organizasyonel öğrenmeyi ilk sunanlar Kurt ve March'tır(1963). Kurt ve March, organizasyonların, yeni koşullara uymak için dış çevrelerindeki değişikliklere yanıt vermeye yönelik çabalarının, organizasyonların daha etkin olmalarına yardım edecek süreçler bulmalarına yol açacağına inanıyorlardı (Saadat, Saadat, 2016 :221)

Organizasyonel öğrenme tartışmalarının tarihine karşın bu başlık 1970 yılına kadar pek ilgi çekmedi. Sonra bazı kuramcılar kendi çalışmalarına başladılar. Yirminci yüzyılın dokuzuncu on yılında bu başlık yeniden doğdu. Organizasyon etkinliğinin niteliği ve öğrenmesinin niteliği son yıllarda dikkat çeken bir başlık oldu.Yine de bu başlık Peter Senge'nin ünlü kitabından önce bilinmedi ve dikkat çekmedi. Peter Senge'nin kitabından önce, organizasyonel öğrenme içeriğini hazırlayan farklı içerikler etkili oldu. Altman ve Les (1998) bu içeriğin biçimlenmesine yardımcı olan dört kuramsal ilerleme tanımladı (Saadat, Saadat, $2016: 221)$.

$\mathrm{Bu}$ dört kuramsal ilerlemeden en ulaşılabilir olanı, organizasyonun rekabet avantajı olarak değerlendirilen ve organizasyonu çevresinden daha bağımsız olmasını sağlayan, organizasyonun potansiyel insan yetenekleri gibi organizasyonun iç süreçlerini esas alan "stratejik yönetim" ilerlemesiydi. Bu içeriğin ortaya çıkarılmasına yardımcı olan ikinci entelektüel süreç "sistemlerin kuramı" gibi kuramlardı. Kuramın üçüncü entelektüel süreci, öğrenmenin farklı düzeyleri üzerine gelişen "sosyal öğrenme" kuramıdır. Son olarak, organizasyonel kültür ve yapı gibi faktörleri göz önüne alan organizasyonel öğrenmenin dördüncü esasını biçimlendiren organizasyon arka planına ilgi gösteren kuramsal süreçtir(Saadat, Saadat, 2016 :221).

Organizasyonel öğrenmenin ana yaşam çevrimi doksanlı yıllarda başladı ve Peter Senge'nin Beşinci Disiplin gibi kitaplar yönetim bilimlerinde bu başlığın zenginliğinin en büyük yansımasıdır (Saadat, Saadat, 2016, :221) 
Bu çalışmada, organizasyonel öğrenme sürecinin adımlarını bir arada görünür hale getirmek amaçlandı ve bu adımların nasıl uygulanacağına dair bir öneri sunuldu.

\section{Organizasyonel öğrenme süreci}

Herkes öğrenme yeteneğiyle dünyaya gelir ve bu öğrenme onları çevresel değişikliklere ve gelişmelere uyum gösterebilir hale getirir. Öğrenme insanda yeni sezgilere ve içeriklere yol açar ve sık sık başımıza geldiği üzere, eylemlerden etkileniriz ve hataları tanımlayıp düzeltiriz (Argyris \& Schön, 1978). Öğrenme, deneyimde değişimler üzerinden bilginin yaratıldığı bir süreçtir (Gholipoor, 2010). Bir bütün olarak öğrenmenin, tekil ya da çoğul olarak yararlı içerikler yaratma olduğu söylenebilir (Saadat, Saadat, 2016 :221)

Öğrenme, bir organizasyonun kesintisiz gerçekleştirmesi gereken sürekli bir etkinliktir (Senge, Beşinci Disiplin, 2016). Çalışanlarda başlayan öğrenme sırasıyla süreçlerde ve ardından organizasyonda gerçekleşir (Sandra Patricia Duarte Apontea \& Delio Ignacio Castaneda Zapata, 2013 :443).

Bir organizasyonda ortaya konulan tüm etkinlikler gibi organizasyonel öğrenmenin de amacl, organizasyonun performansını yükseltmek ya da en azından korumaktır. Genel olarak organizasyonel öğrenme "bir girişimin stratejik yenilenme aracı" olarak kabul edilir (Crossan et al., 1999).

Kavramlaştırma, yönetim, organizasyonel öğrenmenin geliştirilmesi ve kullanılması konusunda çok değişik araştırmalar yapılmış olmasına rağmen, organizasyonel öğrenmenin tanımı, teorisi ve konuyla ilgili genel bir fikir birliği henüz sağlanamamıştır. Bu alandaki uzmanların mutabakat eksikliğinin nedenleri şunlar olabilir:

a.Organizasyonel öğrenme farklı disiplinlerle ilişkilenen bir alan olduğu için, sosyoloji, psikoloji, yönetim, endüstri ekonomisi gibi alanların uzmanlarının her biri, organizasyonel öğrenmeyle ilgili olarak kendi alanlarıyla ilişkili teoriler ve içerikler geliştirmişlerdir (Yeung, Ulrich, Stephen, \& Von Glinow, 1999).

b.Organizasyonel öğrenmenin, bilgi işleme, ürün inovasyonu, organizasyonel değişim, organizasyonel kültür ve strateji uygulamaları gibi farklı alanlarda kullanılması, organizasyonel öğrenmede bir içerik çeşitlenmesine yol açmıştır (Crossan, Lane \& White, 1999).

c.Bireysel düzeyde öğrenmeden organizasyonel düzeyde öğrenmeye yönelik çok katlı öğrenme içeriği analizleri bu çeşitliliğe yol açmıştır (Templeton, Lewis \& Snyder, 2002).

Bu stratejik içeriği görünür kılan bazı tanımlar şunlardır :

-Garcia Moralez et al. Organizasyonel öğrenmeyi, organizasyonun, önceki deneyimleri esas alarak performansı koruyup geliştirme ve bilimi paylaşılır kılmanın olanaklarını organizasyonda kullanma yeteneği olarak tanımlar (Crossan, Lane\&White, 1999).

-Organizasyonel öğrenme, organizasyonun sürekli ilerlemesi iddiası üzerinden düşünce ve üretim yeteneğinin gelişimini açılar (Marquard, 2002).

-Chris Argyris organizasyonel öğrenmeyi bir keşif ve hataları düzeltme süreci olarak tanımlar (Malek-poor, Sefidi, 2006). 
-Organizasyonel öğrenme, öğrenmeye ulaşmak için kullanılan tüm yöntem, mekanizma ve süreçlerden meydana gelmiştir (Mayo, 1994).

Organizasyonel öğrenme hataları ve yanlışları bulma ve onları çözüp düzeltme sürecidir. Zaman içinde bilimle ve performans geliştirmeyle gerçekleşir (Alvani, 2008).

Bu tanımlardan yola çıkarak, bütün organizasyonlarda öğrenme, organizasyonel, grupsal ve bireysel olarak farklı düzeylerde gerçekleşir. Bireysel düzeyde öğrenme, bir kişinin çevresine ait olan bilgileri anlamasını, yorumlamasını, onları denemesini ve davranışlarını, içeriğe dair ve algısal süreçler üzerinden bunlara ayarlaması olarak açıklar. Sonuç itibarıyla, sezgi ve yorumlama bireysel etkinliktir. Bir organizasyonun sezgisi ya da yorumu olmaz. İnsanların sezgileri ve yorumları olur. İkinci öğrenme düzeyi olan grupsal öğrenme, bireysel düzeyde öğrenmiş insanlara dairdir. Öğrendiklerini grupla paylaşırlar, birlikte yorumlarlar ve bir grup kabulüne ulaşırlar. Burada insanların iletişim sürecinden yararlanmaları önemlidir. Grupsal öğrenme olmadan organizasyonel öğrenmeden söz edilemez. Organizasyonel öğrenme ise, grup düzeyinde elde edilmiş ortak değerleri ve kabulleri, sistem, yöntem ve tüm organizasyon için kabul edilebilir bir yönerge çerçevesinde beklenen davranışsal kalıpları ve onların ihtiyaç duyan herkesin ulaşabileceği bilgi temellerine dönüştürülmesi olarak açıklanabilir (Saadat, Saadat, 2016 :225). Burada önemli olan organizasyon aracılığıyla öğrenmedir (Amir Kabiri, 2006).

Organizasyonel öğrenmenin çok boyutlu bir içeriği olduğuna dair de bir genel kabul vardır (Senge, 1990 ; Slater and Narver, 1994, 1995 ; Jerez Gomez et al., 2004 ; Chiva et al., 2007 ; Tohidi et al., 2012). Bu bağlamda, Slater ve Narver (1994), “ organizasyonel öğrenmenin farklı algısal düzeylerde ortaya çıkan, karmaşık ve çok sayıda alt süreci kucaklayan çok boyutlu bir yapı olduğuna" işaret etmişlerdir. Yine de organizasyonel öğrenme çalışılırken farklı bakışlar uyarlandığı için bu bağlamda tanımlanan boyutlar da farklıdır ( Chiva, et al., 2007). Organizasyonel öğrenme alanında genel olarak iki yaklaşım uyarlanmıştır (Tsang, 1997). Bunlardan biri, organizasyonel öğrenmeyi organizasyonların öğrendikleri ve bilgilerini geliştirdikleri bir süreç olarak tanımlar ( Huber,1991 ; Slater and Narver, 1995 ; Jimenez and Sanz, 2006 ; Jyothibabu et al., 2010 ; Flores et al., 2012). Bu süreç Huber(1999)'i izleyerek ayrıca dört alt süreçle ilişkilenmiştir: bilginin elde edilmesi, dağıtımı, yorumlanması ve belleğe alınması. Bu alt süreçlerin her biri böylece organizasyonel öğrenme sürecinin boyutları olarak değerlendirilmiştir ( Chiva et al., 2007).

İkinci yaklaşım ise organizasyonel öğrenmeyi, öğrenmeye organizasyonel uyum ya da organizasyonel öğrenme sürecini kolaylaştıran bir organizasyonel yetenek olarak tanımlar (Garvin, 1993 ; Jerez Gomez et al., 2004 ; Chiva et al., 2007 ; Camps and Luna-Aroca, 2012). Bu bağlamda Garvin (1993), öğrenen organizasyonun bilgiyi yaratmak, elde etmek, transfer etmek ve davranışlarını yeni bilgi ve kavrayış çerçevesinde dönüştürebilme konusunda becerikli bir organizasyon olduğunu söyler. Böylece, organizasyonel öğrenme yeteneği, organizasyonel öğrenme sürecini kolaylaştıran ya da organizasyonun öğrenmesine olanak veren organizasyonel yönetim karakteristiklerinden biri olarak tanımlanır (Chiva et al., 2007 ; Tohidi et al., 2012). Bu bakışa göre organizasyonel öğrenme içeriğinin boyutları onun ana kolaylaştırıcılarıdır ( Chiva et al., 2007). 


\section{Organizasyonel öğrenme sürecinin adımları}

Birbirini tamamlayan ve destekleyen bireysel, grupsal ve organizasyonel öğrenme süreçlerinin üçünü de kapsayan organizasyonel öğrenme sürecinin şu adımlardan oluştuğunu ifade edebiliriz:

1. Bilginin ortaya çıkarılması (Daft \& Weick, 1984)

2. Bilginin paylaşılması (Nonaka \& Takochi, 1995)

3. Bilginin tartışılması değerlendirilmesi ve bilgide ortaklaşma (Orthner, Cook,Sabah, Rosenfeld, 2006 Argyris \& Schön, 1978,1996)

4. Ortaklaşılan bilginin uygulanması ve sürece katılması (Orthner, Cook, Sabah, Rosenfeld / Ho Wook Shin, Joseph C. Picken, Gregory G. Dess))

5. Sürecin her adımı itibarıyla kayıt altına alınması (Zollo \& Winter 2002).

\section{Bilginin ortaya çıkarılması}

Bilginin ortaya çıkarılmasına başlamadan önce bir yapı olarak bilgiyi tanımlamak gereklidir. Bilgi, Nonaka ve Takeuchi (1995) tarafından organizasyon kapasitesini etkili eyleme dönüştüren "makul gerçek inanç" olarak tanımlanmıştır.

Bilgi bireylerde bulunabilir yahut da bir grup ya da organizasyona dağıtılmış olabilir (Hall\&Adriani, 1998 ; Yang \& Wan, 2004.) Çoğu araştırmacı, organizasyonel bilgiyi, organizasyon üyesi bireylerin sahip olduğu toplam bilgiden farklı bir içerik olarak değerlendirir(Brown \& Duguid, 1991 ; Nahapiet \& Ghoshal, 1998). Bu, bir bütün olarak firmanın tanımına bağlıdır ve ne tek bir bireyin bildiğiyle ne de organizasyonun çalışanları, donanımı ya da tesislerinin temsil ettiği farklı yetenek ve olanakların toplamıla sınırlanamaz (Nelson \& Winter, 1982). Organizasyonel bilgi beyan edilen bilgi ve usule dair bilgi olarak nitelenebilir (Akgün, Dayan \& Di Benedetto, 2008; Moorman, Miner, 1997). Beyan edilen organizasyonel bilgi daha geneldir ve geniş bir aralıktaki durumlara uygulanabilmek üzere, içerikleri, gerçekleri, ya da olayları referans alır (Kyriakopulos, 2011). Usule dair organizasyonel bilgi ise, belirli bir alana özgü becerilerle ilgilidir ve rutinleri, süreçleri ve prosedürleri referans alır (Tippins \& Sohi, 2003). Organizasyonel görevlere ve etkinliklere daha fazla yakınlık ve deneyim (usule dair organizasyonel bilgi) sezgi yeteneğini geliştirir fakat bütün bunların dışında iç bireysel bilgiyi bir araya getirmeyi ve çevresel değişimlere adapte etmek için organizasyonel görev ve etkinliklerin orkestrasyonunu mümkün kılar (Julia Nieves \& Sabine Haller (2013), s: 226).

Crossan et al. (1999) organizasyonel öğrenmenin dört mikro süreçle birlikte ilerlediğini tartışmışlardır: esinlenme, anlama, içselleştirme ve kurumsallaştırma. İçselleştirme ve kurumsallaştırma bağlamında, bu araştırmacılar, organizasyonel öğrenmenin yeni bilginin özümsenmesi ve eski bilgiden yararlanılması arasında gerilim yaratan bir süreç olduğuna vurgu yapmışlardır. (Crossan et al., 2011) Böylece öğrenme süreçleri, keşfe ve kullanmaya bağlidir.

Bu öğrenme süreçleri şirketin mevcut üretim süreçleri ve ürünlerini geliştirmelerini sağlar ve yeni süreçlerde, hayatta kalabilmek için zorunlu bilgi gruplarının inşa edilip geliştirilmelerinde kullanılmak üzere bilgi yaratır (Brix \& Peters, 2015; Tushman, Smith, Wood, Westerman, \& Reilly, 2010). Crossan et al.'1 (1999) tamamlamak üzere, Argote'ye göre 
(2011) organizasyonel öğrenme süreci şu üç adımı kullanarak mümkün olabilir: bilgi yaratma, bilgiyi tutma ve bilgiyi transfer etme. Argote'ye (2011) göre, organizasyonel öğrenme bireysel öğrenmenin tersine, yeni bilgi, veri tabanlarına, araçlara, rutinlere ve sosyal ağlara yüklendiklerinde ilk olarak ortaya çıkar. Argote'ye(2011) göre organizasyonel öğrenmenin ilk adımı bilginin ortaya çıkarılmasıdır (Brix, 2017 : 114, 115).

Nonaka ve Takeuchi'ye göre bilgi içeriğinin sözsüz ve açık olmak üzere iki boyutu vardır. Açık olan, sözlü, konuşulan, belgelerde iletişime konu olan ve veri tabanlarında yüklü bulunan bilgiyi referans alır. Sözsüz boyut ise, bireyin deneyim, düşünce ve duygularını referans alır. Bunlar da bağlam çerçevesinde teknik know-how ve becerilere bağlıdır. Sözsüz ve açık boyutları tamamlamak üzere Choo (1998) üçüncü bir boyut ileri sürer: kültürel bilgi. Bu boyut, "yeni bilgiye değer ve önem atfetmek üzere kullanılan gelenek ve beklentiler kadar gerçekliği tanımlamak ve açıklamak için kullanılan kabuller ve inançlar"a bağlıdır (Choo, 1998). Choo'ya göre kültürel bilgi zaman içinde, bir grup ya da organizasyonu oluşturan bağlar ve ilişkilere bağlı olarak yayılır ve gelişir. Nonaka ve Takeuchi (1995) bilginin bireysel düzeyde ve sosyal (kollektif bilgi) düzeyde var olabileceğine vurgu yapar. Bireysel bilgi ve sosyal bilgi arasındaki bağ, bireyler günlük işlerinin anlamını tartışıp birbirlerine anlattıkça organizasyondaki kültürel bilginin unsurları tarafından yönlendirilir. Ayrıca Brix, SOLO(Structure of Observed Learning Outcome) Taxonomy (Biggs\&Tang, 2009) kullanarak bilginin pek çok düzeyde var olabileceğini göstermiştir. Bir arabayı tanımlamakla, o arabayı a'dan b'ye güvenlik içinde götürmek arasında büyük fark vardır. Yine de bir araba sürmeyi öğrenme süreci, algısal düzeyde nasıl yapıldığına dair ve yapabilmenin motor becerilerinin koordinasyonu gibi pek çok düzeyde bilgi edinmeyi kapsar. Bu bilgi yaratma (bilginin ortaya çıkarılması) tartışmasına götürür.

Çalışanlar arasında bilgi paylaşılmasını kolaylaştıran firmalar bundan çok önemli yararlar sağlarlar. Öğrenen organizasyon liderleri şu yolları izleyerek yatırımlarını iç bilgiyle etkinleştirmenin yollarını bulmuşlardır:

-Çalışanları, sorular sorma ve ilgi duydukları konuları ifade etmeleri yönünde cesaretlendirme,

-Faklı kaynaklardan bilgileri geniş biçimde paylaşma konusunda cesaretlendirme,

-Firsatlar yaratarak yeni fikirlerin denenmesini güvenli hale getirme,

-Ortak kararlar verme ve en iyi uygulamaları paylaşma konusunda cesaretlendirme

-Bilginin temini ve paylaşımını kolaylaştırmak için teknoloji sağlama

Öğrenme sürecinde bilginin ortaya çıkarılması, bir kaynak, farkındalık ve etkinlik konusudur. Üretimin herhangi bir sürecine dair öğrenmede en zengin öğrenme kaynaklarından biri bireyin ve organizasyonun o sürece dair deneyimleridir. Bu kaynak bireyin içinde üretime katıldığı sürecin kendisi ve o süreç çerçevesinde yaşananlardan oluşur. Organizasyon hedefleri bağlamında öğrenmeyi amaçlayan bir birey için son derecede zengin bir kaynaktır. Yürüyen bir süreçte organizasyon hedefleri bağlamında yeni bilginin bir başka önemli kaynağı ise bireylerin gözlemleridir. Bunların ardından kaçınılmaz olarak ortaya çıkacak soruların yanıtları ise araştırma ile aranacaktır. 


\section{Bilginin paylaşılması}

Bireysel öğrenmenin organizasyonel öğrenmeye dönüşümü, bir organizasyon üyesinin bilgi üretmesi ya da edinmesi ve bilgiye bir ortaklık anlamı vererek diğerleriyle paylaşması ile gerçekleşir (Crossan, Lane \& White 1999; Huber, 1991). Bartol ve Srivastava (2002) bilgi paylaşımını çalışanların uygun bilgiyi organizasyon boyunca diğerlerine yaymaları olarak tanımlıyor. Bock ve Kim'e göre (2002) ise, bilgi paylaşımı bilgi yönetiminin en önemli kısmıdır. Çalışanların bilgi paylaşımının nihai amacı ise bilginin organizasyon varlıklarına ve kaynaklarına aktarılmasıdır (Dawson, 2001). Öte yandan, etkinliklerin paylaşımı gönüllü olmak zorundadır ve zorlanamaz (Kaser \& Miles, 2002). Bir çalışanın davranışları ve yetkinlikleri bilgi paylaşımını engelleyebilir. Kimi bireyler, bilgisiz görünüp muhtemel kariyer fırsatlarına uygun bulunmamak gibi korkularla paylaşma konusunda davranışsal bir isteksizliğe sahiptirler. Çalışanlar keza kendi bildiklerini paylaştıktan sonra, üstünlüklerini ve bilgi mülkiyetini kaybetmekten korkarlar (Bartol ve Srivastava,2002 ;Szulanski, 1996). Hislop'un çalışması (2003) bilgi paylaşımında en önemli etkenin çalışan davranışları olduğunu, çalışanın paylaşma motivasyonu olmadığını ortaya koyar. Wah (2000) bilgi yönetimi kurmanın önündeki önemli bir engelin insanların bilgiyi saklama eğilimleri olduğunu söyler. Gerçekten de "bilgiyi saklama” diye bir şey vardır. Hatta paylaşma, mevcut kazançlar, kayıplar ve "bilgi güçtür" vasatında doğal görülmez. Bilginin, paylaşıcıların tümü yerine seçilmiş koşulların vakalarını paylaştı̆̆ı kısmi transferi, bilgi saklamanın daha yaygın bir biçimi olabilir (Goh, 2002) (Yang, 2008 :347).

Bilgi yaratma (ortaya çıkarma) süreci, bir farkındalık yaratma süreciyle ortaya çıkarılmış kişisel bilgiyle bireysel düzeyde başlar (Cohen \& Levinthal, 1990; Nonaka, 1994; Weick, 1995). Birey kendi kişisel bilgisini diğerleriyle paylaşmaya başladığında diğerleri bunu edinmek ve anlam yüklemek durumunda kalır (Cohen \& Levinthal, 1990; Nonaka \& von Krogh, 2009). Bu etkileşim, hem farkındalık yaratma hem de farkındalık önerme süreçlerini temsil eder(Gioia \& Chittipeddi, 1991). Kişiler arası etkileşimle, ortak bilgi, anlamının da tartışıldığı ortak farkındalık yaratma süreci olarak ortaya çıkarılır (Nonaka \& von Krogh, 2009). Bu düzeyde organizasyonel öğrenme ortaya çıkmamıştır çünkü yeni kişiler ve ortak bilgi kaydedilmemiştir ve yenileşmenin yaratılması amacıyla organizasyonel yapıya uygulanmamıştır (Argote, 2012 ; Crossan \& Berdrow, 2003 ; Crossan et al., 1999 ; Jensen, Johnson, Lorenz, \& Lundvail, 2017).

\section{Bilginin değerlendirilmesi}

Bilgi paylaşılması bireysel bir etkinliktir. Bu haliyle henüz organizasyona mal olmamıştır ve organizasyonel öğrenmeye konu edilmemiştir. Çalışanların bilgi paylaşımını izleyen adım organizasyona (bu cümleden olarak organizasyonel işleyişe de) dair bilgi, düşünce ve yargılarda ortaklaşılmasıyla sonuçlanacak bir dizi görüşmeler ve tartışmalardır. Tartışmalar, süreç ve elbette organizasyon performansını arttırmayı hedefleyen ve bu hedefe uygun başlıklar altında yürütülecektir. Böylece, tartışmalar, tartışma içeriğini kendi bulundukları yerlerden bakarak değerlendiren çalışanlara, konulara farklı açılardan bakma olanağ verecektir. Bu, hem öğrenme hacmini büyütecek hem de bir ortaklaşma zemini yaratacaktır. Ortak bilgi, etkileşen tüm kişilerin kişisel bilgisinin tartışıldığ bir ortak farkındalık yaratma süreci içinde ortaya çıkarılır (Nonaka \& von Krogh, 2009). Kaldı ki etkili bir öğrenen organizasyondan beklenen, organizasyondaki bireylerin zihni modellerinin birbirlerine yakınlaşması ve ortak amaç ve tercihler biçiminde ifade edilen bir paylaşılan vizyon ile sonuçlanmasıdır. Bu paylaşılan vizyon, ortak gerçeklik ve kısıtların farkındalığından 
çıkmalıdır. Böyle bir yakınlaşmanın dışavurumları, etkili bir organizasyonel öğrenmenin göstergesidir. Organizasyonel öğrenmenin içeriği, ortak eylemle tatmin edilecek bir ortak istek olduğunu ve dahası öğrenme ile ulaşılabilecek ortak ilerleme potansiyeli olduğunu var sayar. Burada temel olarak üç kritik konudan söz edebiliriz: Birincisi, ortak olarak arzu edilenler yani tercihler, ikincisi ortak araçların hangi tercihlerle tatmin edileceği ve üçüncüsü, tatmini artırmak üzere bu araçların kullanılacağı yol ve yöntemler kısaca bu bir üretim sistemidir. (J.Michael Spector, Pal I. Davidsen, 2006 :66).

Bilgi işleme-ve değerlendirme- yetenekleri organizasyonların, organizasyonel bilgiyi elde ettikleri, paylaştıkları ve ondan yararlandıkları sistematik bir süreçtir. Süreçler, araştırmacıların kabullerine ve çalışmalarının tabiatına göre farklılıklar gösterir. Örneğin, süreçler, elde etme, dönüştürme uygulama ve koruma (Gold et al., 2001 ; Fan et al., 2009 ; Liu \& Deng, 2015); elde etme dönüştürme ve uygulama ( Ju et al., 2006), elde etme, arıtma, depolama ve paylaşma (Liu et al., 2004); yaratma, transfer etme, entegre etme ve uygulama(Wu \& Chen, 2014) ; transfer etme, dönüştürme, koruma (Tseng \& Lee, 2014 ; Tseng, 2014) ; elde etme, paylaşma, uygulama (Gharakhani \& Mousakhani, 2012) ; elde etme, yayma, yararlanma (Chen \& Fong, 2012) biçiminde farklılıklar gösterebilir. Ezcümle, bilgi işlemedeğerlendirme- yetenekleri iç ve diş kaynaklardan bilgi edinerek başlayan sistematik süreçler olarak değerlendirilir. Ardından, yeni bilgi yaratmak ya da tekerleğin yeniden icadını önlemek üzere bilgi, yeni bilgi yaratmak için organizasyon üyeleri arasında paylaşılır. Son olarak, paylaşılan bilgiden organizasyon ve üyelerince yararlanılır. (Alaarj, Mohamed, Binti, Bustamam, 2016 :730).

Bilginin tartışılması, değerlendirilmesi ve bilgide ortaklaşma sürecinde kritik etmenlerden biri de güvendir. Güven, organizasyonel rolleri, ilişkileri, deneyimleri ve karşılıklı bağımlılıkları çerçevesinde çok farklı organizasyon üyelerinin niyet ve davranışları konusunda bireylerin olumlu beklentisi olarak tanımlanır (Shockley-Zalabak et al., 2000).

Pek çok durumda bir organizasyonun üyeleri arasında güvenin varlığı, rekabet avantajı ya da dikkat çeken bir organizasyonel yetenek olarak zemin yaratır (Zanini \& Migueles, 2013). Güven, performans ve kriz zamanlarında organizasyonel üyelerinin iyi hissetmeleri için önemlidir (Mishra, 1996). Güven varlığı, bİlgi paylaşma kültürünü ve bilgi transferini yükseltir (Sandhawalia\&Dalcher, 2011). Diğer yandan güven eksikliği, çalışanların bilgi ve deneyimlerini organizasyonun diğer üyeleriyle paylaşmamalarının nedeni olarak ifade edilmiştir (Currie\&Kerrin, 2003; Gharakhani\&Mousakhani, 2012; Holste \& Fields, 2010). Literatürden kanıtlar, güvenin, bilgi paylaşımı, elde edilmesi ve transferi konusunda aracı rolü olduğunu göstermiştir ((Lewin\&Cross, 2004; Niu, 2010). (Alaarj, Mohamed, Binti, Bustamam, 2016 :731).

$\mathrm{Bu}$ çerçevede, bilginin tartışılması değerlendirilmesi adımı, bilginin ortaya çıkarılması ve bilginin paylaşılması adımlarının ardından organizasyonel öğrenmenin görünür hale geldiği adımdir.

\section{Ortaklaşılan bilginin sürece katılması}

Ortaklaşılan bilgi bir yandan mevcut bilgiyi diğer yandan da yeni bilgiyi içerir. Organizasyonel performansın gelişiminin, aynı zamanda bu ortaklaşılan bilginin uygulanmasının bir çıtısı olması beklenir. O nedenle performansı yükseltmek üzere, ortaklaşılan bilginin hızla mevcut işleyiş̧ içinde uygulanması gerekir. Öğrenmenin sürekli bir 
hal olmasının önemi burada ortaya çıkar. Bu uygulamanın yakından takibiyle, uygulamanın verdiği sonuçların değerlendirilmesi sürmekte olan bir "öğrenme" halidir.

Ortaklaşılan bilginin uygulanmasıyla organizasyon, organizasyonel bilgiden yararlanmaya başlar. Bilgiden yararlanma, yeni transfer edilmiş bilginin, performans çıktılarını geliştirmek üzere, işletme rutinlerinin düzenlenmesi ve yaratılması olarak tanımlanır (Lee et al., 2011). Daha önceki çalışmalar, organizasyon performansında bilginin etkisini görmek için, organizasyon sürecinde etkili biçimde kullanılmalıdır. Bilgiden elde edilecek yararlar ancak elde edilmiş ve paylaşılmış bilgiler organizasyon performansını etkileyecek yeteneklere dönüştürüldügünde gerçekleşir (Seleim\&Khalil, 2007; Zahra\&George, 2002, Alaarj, Mohamed, Binti, Bustamam, 2016 :733).

Uygulamadan alınan sonuçların -yine bir öğrenme fonksiyonu olarak- değerlendirilmesi sonucunda başarılı bulunanları, yani organizasyon performansının artışına yol açanları artık organizasyon tarafından edinilecektir ya da başka bir deyişle ilgili olduğu sürece katılacak ve o süreci yöneten bilginin bir parçası, tamamlayanı olacaktır. Bu bilginin bir paralel etkinlikle kayıt altına alınmasıyla öğrenme süreci bu bilgi düzeyinde ve ölçeğinde tamamlanacaktır.

\section{Sürecin her adımı itibarıyla kayıt altına alınması}

Bilgi, işleyiş performansını yükseltmek üzere paylaşılıp içselleştirildikten sonra bireyler ve organizasyonlar bu bilgiyi düzenleyerek ve yönergeler gibi her türlü aracı kullanarak organizasyonel hafızaya almalıdırlar (Zollo \& Winter 2002). Dahası, Zollo ve Winter, organizasyonel hafızanın bu düzenlenmiş sürecinin, organizasyonel bilginin etkili bir yayılmasına yol açtığını söyler. Bu bilgi, önceki bireysel deneyimler, mevcut iç rutinler, yeni işletim rutinleri ve organizasyon yönetimine dair her tür bilgiyi içerir.

Hickins'e göre (2000 :102) "insanlar bilgi varlığına içerik ekleme konusunda isteksizdir. Ve herkes de veri tabanının içerdiği bilgi kadar değerli olduğunu bilir". Bilgiyi tutma ve muhafaza etme önemli bir süreçtir. Bilgi yönetimi, bazıları bilgi ağları ve teknolojileri konusunda, toplamak, planlamak ve organize etmek konusunda sorumlu olmadıkça başarılı olamaz. Gerçekte, bilgi konuşularak ve rutinler içinde kullanılarak transfer edilebilir. Ancak, şu da mümkündür ki, insanlar açık kayıtları organizasyonel sistemin bir parçası olarak akılda tutmaz. Çalışanlar gelip gittikçe ve liderlik ya da sahiplik değiştikçe, bilgi dağılabilir. Bu konuda bir saptama, “organizasyonlar tesadüflerle öğrenir ve öğrendiğini nadiren organizasyonel belleğe eklenebilir bir bilgi olarak dönüştürülebilir ve bir biçimde muhafaza edebilir" diyen Wagner (2003:98) tarafından yapılmıştır.

Argote'nin (1999) organizasyonel öğrenme araştırması, bilginin üç farklı bellek sisteminde saklandığını gösterir: bireysel bellek, bir organizasyonun bilgi teknolojileri ve araçları ve onun yapısı ve rutinleri. Çalışan dönüşümü yüksekse ve bireysel bilgi muhafaza edilemiyorsa her üçü de bundan zarar görür. Bireysel bilginin herkesin ulaşabileceği bellek sistemlerine yerleştirmek insan kaynakları yöneticilerinin önemli bir konusudur ve özellikle yüksek işgücü dönüşümü koşullarında bu daha da çok böyledir.

Böyle bir sisteme otel endüstrisinden ilginç bir örnek, Marriot zincirinin çalışanların günlük operasyonlar ve standart operasyon süreçlerine dair bilgilerinin kalıcı müşteri servisi sağlayabilmek için depoladığı "kodlama sistemi"dir (Gupta \& Govindarajan, 2000). Buna aynı zamanda, işe uygun yeni bilgi paylaşanlar, yaratan ve yayanlar için bir ödül sistemi eşlik etmiştir (Ritz Carlton zincirinde benzeri bir uygulama, ilk ziyaretlerinde konukların özel ilgi 
ve meraklarını sonradan kişiselleştirilmiş muamele için kullanılmak üzere kaydederek müşteri bağlılığını desteklemektedir) (Davenport, Harris \& Kohli, 2001) (Yang, 2008 :348).

\section{Organizasyonel öğrenme sürecinin adımları nasıl gerçekleştirilir?}

\section{“Bilginin ortaya çıkarılması" nasıl gerçekleştirilir?}

Bilginin ortaya çıkarılması, var olan bilginin uygunlaştırılması ve tümleştirilmesiyle yeni bilgi üretilmesi sürecidir. Mitchell ve Boyle (2010), bilginin ortaya çıkarılması, yeni fikirlerin yaratılması, geliştirilmesi, uygulanması ve onlardan yararlanılması üzerine vurgu yaparlar. Bilgi yaratılması ve aktarımı, bilgiden yararlanma ve bilginin keşfinin öncesidir (Horng, Tswei \& Chen, 2009). Styhre, Roth ve Ingelgard (2002), bilginin ortaya çıkarılmasını, üzerinden yeni fikirlerin yaratıldığı, şirket için etkinlikler, karşılıklı etkileşimler ve diğer mekanizmaların gerçekleştiği yöntem olarak tanımlar. Bilgi iş uygulamaları sırasında ortaya çıkarılır. Bilginin ortaya çıkarılmasında deneyimleme ve deneyimlere yansıtma anahtar süreçlerdir(Sujatha, Krishnaveni, $2017: 46)$.

Bilginin ortaya çıkarılması, önceden ortaya çıkarılmış ya da çıkarılacak bilginin içeriğine odaklanmayla ilgilidir. Bilginin ortaya çıkarılması, eylem ve etkileşimlerin farklı sosyal ve algısal süreçler marifetiyle bireysellikle ya da birlikte nasıl farklı türden bilgilerin ortaya çıkarılabileceğine dairdir(Brix, 2014 ; Lyles, 2014 ; Nonaka et al., 2014).

Argote(2003)'nin önerdiği üzere bilginin ortaya çıkarılması, organizasyonlarda bilgi yönetiminin önemli çıktılarından biri haline geldi. Nonaka(2000)'ya göre, organizasyonel bilgi yaratımı ve dönüşümü iki boyuta dayanır. Birinci boyut yalnızca bireylerin bilgi yaratmasıdır. İkinci boyut sessiz bilgi ile açı bilgi arasındaki etkileşimle ilgilidir. Bu iki boyut, bilginin ortaya çıkarılmasının dört sürecinin tanımlanması için zemini biçimlendirir.

-Sosyalleştirme: Sessiz bilgi, tartışmalar ve toplantılar sırasında yine sessiz bilgiye dönüşür.

-Dışsallaştırma: Sessiz bilgi, açık bilgiye dönüşür ve belge ve yönergelerde yerini alır.

-Birleştirme: Açık bilgi, açık bilginin bir başka biçimine dönüşür.

-İçselleştirme: Açık bilgi, bireyler tarafından sessiz bilgiye dönüştürülür.

SECI modeli olarak bilinen bu dört yol, başlangıcı ve sonu olmayan bir bilgi dönüşüm spirali belirler. Bu sürekli ve dinamik süreç bilgi yaratan gerçek temsilciler olan bireylerin davranışlarında kökleşir. Nonaka, organizasyonel bilginin ortaya çıkarılması için beş adımdan oluşan bir model değerlendirir. Beş adım:

-Sessiz bilgiyi paylaşma: sosyalleştirmeyi işaret eder

-İçerikler yaratma: paylaşılan bilgi, yeni içerikler yaratılarak açık bilgiye dönüşür.

-İçerik kanıtı: yeni içeriklerin ayarlanması, organizasyonun devam etme kararına olanak verir.

-Bir model kurma: içerik, bir modele prototipe ya da işletim mekanizmasına dönüştürülür.

-Bilginin yayılması: bu adımda, ortaya çıkarılan bilgi tüm firma boyunca yayılır.

Organizasyon yönetimlerinin sessiz bilginin ortaya çıkarılmasını teşvik etme kararlılığını büyütmeleri önemlidir (Sanchez, Sanchez, Ruiz, Tarrason, 2013 :390,391). 
Sessiz bilginin açık ya da kodlama denilen anlaşılabilir biçime tercüme edilmesi bilgi saklama ve yayma gibi diğer bilgi yönetimi süreçlerini kolaylaştırır. Bu hal, her bireyde tutulan bilginin, takımın tüm diğer üyelerine ve tüm organizasyona transfer edilebilmesi için tanımlanmış bir süreç önerir. Bunun için iyi bir uygulama, bu sessiz bilginin organizasyon içine, yeni işçilerle paylaşmak üzere bir rapor hazırlamaktır. Amaç sessiz bilginin aktarılması için bir süreç yaratmaktır. Bu adımda, bir bireyin daha önceki adımlarda gerçekleştirdiği bir etkinliğe bağlı sessiz bilgiyi transfer etmek üzere bir yol bulmayı amaçlıyoruz. Bu yol belli özelliklere sahip olmak zorundadır öyle ki birey sessiz bilgisini açık ve doğru biçimde taşıyabilsin. Bu özelliklerin arasında:

-beceri geliştirme sürecini tanımlamaya olanak verecek bir ifade ortaya koyma,

-çevreden elde edilmiş beceri geliştirme sürecini açılama ve

-bunu 30 dakikayı geçmeyen bir sürede ortaya koyma

bulunmalıdır ve önemlidir.

Uygulanabilecek araçlar arasında en uygun olan, şirket içinde bilgi ortaya çıkarıp paylaşma kültürüne olanak vermek üzere farklı düzeylerde düzenli atelyelerin organize edilmesidir. Bu atölyeler, bilgiyi yönetmeyi ve onunla çalışmayı, bilgiyle çalışacak topluluklar inşa etmeyi, bilginin yeniden tasarlanması ve tutulmasını, becerilerin inşa edilip bildirilmesini, bilgi etkinliğinin geliştirilmesini ve son olarak bilgiyi destekleyen bir kültür oluşturulmasını olanaklı kılacaktır. Bu atölyeler, bir sorular serisi ile her bireyin sahip olduğu doğal bilgiyi keşfeden her birey, her grup ve bir bütün olarak şirketteki bireysel bilgiyi ortaya çıkarmaya olanak veren kişisel bilgi yaratma ve paylaşma atölyeleridir. Böylece, hangi etkinliklerin bu beceri/bilgilere ulaştırabileceği keşfedilebilir, mümkünse o bilgiler, diğer çevresel değişkenlerden ayrılır ve kısa sürede uygulanır (Sanchez, Sanchez, Ruiz, Tarrason, 2013 :395).

Jacubic(2008), bilginin ortaya çıkarılması konusunda, mikro düzeyde karşılıklı etkileşim ve birlikte öğrenme yaklaşımına odaklanmıştır. Katılımcılar arasında daha fazla etkileşim bilginin ortaya çıkarılması sürecini büyütür. Topluluğu oluşturan bireylerin çeşitliliği de bilginin ortaya çıkarılması sürecine etkisi vardır. Birlikte geçirilen zaman, güven ve öğrenme yaklaşımına yatkınlık karşılıklı etkileşim sayısını arttırır.

Lindblom ve Tikkanen (2010) ile Nonaka, Toyama ve Konno (2000), özel bilgi ve yeteneklerin doğru karışımına sahip bireylerin seçiminin bilginin ortaya çıkarılmasını yönetmede anahtar olduğunu söylüyorlar. Doğru özel bilgi karışımına sahip katılımcılardan oluşan departmanlar arası bir takım süreci hızlandırır (Lou, 2008). Bu, çalışanların diyalog başlatmalarına ve karşılıklı etkileşimi geliştirmelerine yardımcı olur.

Spraggon ve Bodolica(2008), fikirlerin insanların aklında ortaya çıkmalarına rağmen, bireyler, gruplar ve organizasyonlar arasındaki karşıllklı etkileşimlerin, yeni fikirlerin ortaya çıkmasında çok önemli rol oynadığına işaret etmişlerdir. Sürekli iletişim, değişim ve karşılıklı etkileşim bilginin ortaya çıkarılmasında esastır. Bilgi yaratmayı destekleyen karşılıklı etkileşim, resmi toplantılarda, gayrı resmi topluluklarda, departmanlar arası takımlarda ve bilgi teknolojileri araçlarında gerçekleşir. "Eylem” sözcüğüyle, yeni bilginin ortaya çıkarılması amacıyla var olan bilginin uygulanması ve işletilmesi anlatılmak istenir. Yaparak öğrenme bilginin ortaya çıkarılmasında esastır. (Sujatha, Krishnaveni, 2017 :47,49). Organizasyonel bilginin ortaya çıkarılması, bilginin şirkette bireysel düzeyde yükseltilmesini ve ifade 
edilmesini kapsar, böylece, firmanın bilgi temelinde içselleştirilir(Sanchez, Sanchez, Ruiz, Tarrason, $2013: 394)$.

Sonuç itibarıyla "Bilginin Ortaya Çıkarılması" şöyle gerçekleşir:

-Şirket içinde bilgi ortaya çıkarıp paylaşma kültürüne olanak vermek üzere farklı düzeylerde düzenli atelyeler organize edilir. Bu atelyeler, bilgiyi yönetmeyi ve onunla çalışmayı, bilgiyle çalışacak topluluklar inşa etmeyi, bilginin yeniden tasarlanması ve tutulmasını, becerilerin inşa edilip bildirilmesini, bilgi etkinliğinin geliştirilmesini ve son olarak bilgiyi destekleyen bir kültür oluşturulmasını olanaklı kılacaktır. Bunlar, bir sorular serisi ile her bireyin sahip olduğu doğal bilgiyi keşfeden her birey, her grup ve bir bütün olarak şirketteki bireysel bilgiyi ortaya çıkarmaya olanak veren kişisel bilgi yaratma ve paylaşma atelyeleridir. Böylece, hangi etkinliklerin bu beceri/bilgilere ulaştırabileceği keşfedilebilir, mümkünse onlar diğer çevresel değişkenlerden ayrılır ve kısa sürede uygulanır (Sanchez, Sanchez, Ruiz,Tarrason,2013 :395).

-Bilgi iş uygulamaları sırasında ortaya çıkarılır. Bilginin ortaya çıkarılmasında deneyimleme ve deneyimlere yansıtma anahtar süreçlerdir. Yaparak öğrenme bilginin ortaya çıkarılmasında esastır. Bilgi yaratmayı destekleyen karşılıklı etkileşim, resmi toplantılarda, gayrı resmi topluluklarda, departmanlar arası takımlarda ve bilgi teknolojileri araçlarında gerçekleşir. "Eylem" sözcügüüle, yeni bilginin ortaya çıkarılması amacıyla var olan bilginin uygulanması ve işletilmesi anlatılmak istenir (Sujatha, Krishnaveni, 2017 :46).

-Önceden ortaya çıkarılmış ya da çıkarılacak bilginin içeriğine odaklanılır. Bilginin ortaya çıkarılması, eylem ve etkileşimlerin farklı sosyal ve algısal süreçler marifetiyle bireysellikle ya da birlikte gerçekleşir(Brix, 2014 ; Lyles, 2014 ; Nonaka et al., 2014).

-Organizasyonel bilgi yaratımı ve dönüşümü iki boyutta gerçekleşir. Birinci boyut yalnızca bireylerin bilgi yaratmasıdır. İkinci boyut sessiz bilgi ile açık bilgi arasındaki etkileşimle ilgilidir. Bu iki boyut, bilginin ortaya çıkarılmasının dört sürecinin tanımlanması için zemini biçimlendirir.

-SECI Modeli uygulanır: Sosyalleştirme: Sessiz bilgi, tartışmalar ve toplantılar sırasında yine sessiz bilgiye dönüşür; Dışsallaştırma: Sessiz bilgi, açık bilgiye dönüşür ve belge ve yönergelerde yerini alır. ; Birleştirme: Açık bilgi, açık bilginin bir başka biçimine dönüşür; İçselleştirme: Açık bilgi, bireyler tarafından sessiz bilgiye dönüştürülür. SECI modeli olarak bilinen bu dört yol, başlangıcı ve sonu olmayan bir bilgi dönüşüm spirali belirler. Bu sürekli ve dinamik süreç bilgi yaratan gerçek temsilciler olan bireylerin davranışlarında kökleşir. Nonaka(2000)

-Organizasyonel bilginin ortaya çıkarılması için beş adımdan oluşan bir model değerlendirilir (Nonaka). Bu beş adım: Sessiz bilgiyi paylaşma: sosyalleştirmeyi işaret eder; İçerikler yaratma: paylaşılan bilgi, yeni içerikler yaratılarak açık bilgiye dönüşür; İçerik kanıtı: yeni içeriklerin ayarlanması, organizasyonun devam etme kararına olanak verir; Bir model kurma: içerik, bir modele prototipe ya da işletim mekanizmasına dönüştürülür; Bilginin yayılması: bu adımda, ortaya çıkarılan bilgi tüm firma boyunca yayılır.

\section{"Bilginin paylaşılması" nasıl gerçekleştirilir?}

Bilginin paylaşılması, kişiler arasında bir karşılıklı etkileşim süreci olarak kabul edilir(Yang, Wu, 2007 : 1134). Bartol ve Srivastava(2002) organizasyon boyunca çalışanların uygun bilgileri diğerlerine yayma eylemi olarak tanımlar. Bock ve Kim(2002)'e göre bilginin paylaşımı bilgi yönetiminin en önemli bölümüdür. Çalışanların bilgi paylaşmalarının nihai hedefi bilginin 
firma varlıklarına ve kaynaklarına aktarılmasıdır(Dawson, 2001). İlave olarak, paylaşma etkinlikleri gönüllülük esaslıdır ve zorlanamaz(Kaser \& Miles, 2002) (Yang, 2008 :347). Bilginin paylaşılması başlığının önemi, bilginin bulunduğu bireysel düzeyle, bilginin uygulanacağı ve değer yaratacağı organizasyonel düzey arasında bir bağ kurmayı amaçlamasındadır. Bireysel ve organizasyonel düzeyler arasındaki bu çatallaşma, uygulamada, bireysel bilginin organizasyonel bilgiyle bütünleşmesinde kökleri hem bireyde hem de organizasyonda olan aşağıda sıraladı̆̆ımız pek çok engel ortaya çıkarır (Riege, 2005) :

-Bilgiyi paylaşmak için zaman yetersizliği

-iş güvenliği tehdidi konusunda endişe

-Yetersiz farkındalık

-Paylaşırken açık bilginin, sessiz bilgiye üstünlüğü

-Bireysel ve organizasyonel öğrenmenin etkilerini arttırabilecek önceki hataların anlaşılması, değerlendirilmesi ve iletişiminde yetersizlik

-Deneyim düzeyleri arasında farklılıklar

-Karşılıklı etkileşim ve sosyal ağ eksikliği

-İletişim ve kişiler arası becerilerde eksiklik

-Yaş, cinsiyet, kültürel ve eğitim farklılıkları

- Kaynaklara göre bilginin doğruluk ve güvenilirliğine yetersiz güven

Bu etmenlerin bazılarının bireysel ve bazılarının organizasyon çevresine, kültürlere vb dayalı nedenleri vardır. O zaman, bu engellerin ortadan kaldırılmaları lazımdır. Bu, ayrıntılı olarak organizasyonun, içsel ve dişsal değer sisteminin bir kombinasyonu olarak, insan bağlantılı etmenler denilen motivasyon, kararlılık, beklentiler ve ödüllere odaklanmalıdır. Çalışanlara, sözcüklerle nakledilen sessiz bilgiyi aktarabilmeleri ve böylece paylaşabilmeleri için zaman, alan ve fırsat verilmelidir. Bu, karar verme süreci, insan kaynakları politikaları, performans ölçütleri vb marifetiyle şirketin kültürü ve organizasyon yapısı tarafından desteklenir (Cook, 2004). Bu başarı etmenlerinden, keza, güçlü bir biçimde ödül sistemleri ile endüstri dinamikleriyle kültür, güç ilişkileri vb gibi sosyo kültürel faktörlerle birlikte organizasyonel roller ve yapı ile arasındaki uyumun altını çizen Hall (2005) da söz etmiştir. Alıcı ve verici arasında iyi ilişkiler, planlı, resmi, gayrı resmi ve rastlantısal iletişimin esasıdır. Açıklandığı üzere, bilgi paylaşma "bilgiyi organizasyon içindeki diğerleri için ulaşılabilir kılma eylemleri"ne dayanır (Ipe, $2003: 32$ ).

Bilginin paylaşılması bilgi yönetiminin temel bir yanıdır ve bireysel bilginin organizasyonel yeteneğe aktarılması için anahtar süreçtir (Dalkir, 2005 ; Foss, 2007 ; Prencipe \& Tell, 2001). Bilginin paylaşımı, "diğerlerine sorunları çözmek, yeni fikirler geliştirmek, ya da politikalar ve prosedürler uygulamak için yardım etmek ve işbirliği yapmak için görev bilgisinin teminidir" (Wang \& Noe, 2010 :117). Diğerleriyle oluşturulan ağ üzerinden yazılı olarak ya da yüz yüze iletişimle ya da bilgiyi diğerleri için belge haline getirme, organize etme ve elde etmekle ortaya çıkar (Wang\&Noe, 2010) (Nesheim, Hunskaar, 2015 :1418).

Bilgi paylaşımında iki esas motivasyon türü vardır. İlki, ölçülebilir bir telafi beklentisi ile ilişkilenen dişsal motivasyondur. Bu tür motivasyondan anlaşılması gereken odur ki, bir hedef (ödül) süreçte ya da etkinlikte çok önemli olmak üzere bireyin tatminle sonuçlanacak 
davranışını etkiler. İkincisi, bunun tersi olarak, bilgi paylaşımında içsel motivasyondur ve davranışla ilgilenir çünkü bu, bireyin değerleri ve ilgileriyle uyumlu olarak bireysel tatminle sonuçlanır. Böylece, içsel motivasyondan beklenen çıktı, dışsal ödülden daha çok davranışla ilgilenen bir süreçtir (Foss et al, 2009; Gagne, 2009; Osterloh \& Frey, 2000, Dasi, Petersen, Gooderham, Elter, Hildrum, 2017, :435). Bilginin paylaşılması, bilgi yönetiminin en önemli kısmı ve meydan okumasıdır (Syed Rahmatullah \& Mahmood, 2013). Dahası, Syed Rahmatullah ve Mahmood(2013) ile Alavi ve Leidner(2001) tarafından, bilgi paylaşımının iş yaşamında bilgi yönetimi sürecinin en önemli kısmı olduğu ifade edilmiştir. Tüm bunları bir araya getirmek üzere, iş yaşamında bilgi paylaşımı şöyle görülebilir:

-Göndericinin bilgisini alıcıyla paylaşması(Cummings \& Teng, 2003).

-Çalışanın organize olma yeteneğini büyütme (Andrawina, R.Govidaraju, T.A.Samadhi, I.Sudirman, 2008).

-Değişen çevreye yanıt vermede daha iyi olma.

-Yeni elde edilen bilgiden yararlanma.

-İş hayatında etkili kararlar verme (Hayati, Paul\&David, 2013)(Razak, Pangil, Lazim, Zin, Yunus, Asnawi, 2015 :547).

İnsanların özel ilgilerinin motivasyonuyla harekete geçtiklerini düşündügüumüzde, ilave bir ödül aldıklarında bir organizasyonda bilgilerini paylaşmaya daha yatkın olurlar. Yeni özel bir bilgiyi elde ettiklerinde ya da yarattıklarında ve böylece organizasyonda sıra dışı bir yarar sağladıklarında, bilgiyi birbirleriyle paylaşmaları durumunda bundan bir yarar sağlama potansiyeli vardır. Ortada ilave bir kazanç sağlama olasılığı bulunduğunda, kendi özel bilgilerin avantajını kaybetme riski potansiyeli olsa bile, insanlar değerli özel bilgilerini paylaşma konusunda harekete geçerler. Bu nedenle, yöneticiler, çalışanlara, onları bilgilerini paylaşmaya cesaretlendirmek için, dişsal ya da doğal ödüller vermelidir. Çalışanı şartlandırma perspektifiyle, olumlu bir çıktısı olabilecek bilginin paylaşılması gibi bir beklenen davranışın güçlendirme süreci etkinleştirilmelidir (B.F.Skinner / The behaviour of organisms: An experimental analysis,1938). Bilginin paylaşımı birey ve gurup arasında bir çıkar çatışmasına yol açar. Taraflar arasında çıkar çatışmasını koordine etmek ve organizasyon içinde bilgi paylaşımını destekleyecek doğru bir özendirme politikası gereklidir. Ancak, bilgi paylaşımını özendirme politikalarının tasarımı ve bunun bireylerin davranışları ve organizasyon üzerine kısa ve uzun dönem etkileri üzerine çok az çalışma ortaya konmuştur.

Paylaşılan bilginin niteliğini ölçmek zor olduğundan uygulamada çalışanlara paylaşım davranışının ortaya çıkma sıklığı esas alınarak ödüllendirilirler. Böylece, yöneticiler, düzenli ya da düzensiz olarak bilgi paylaşma sıklığını gözden geçirir ve ne kadar teşvik sağlanacağına karar verirler. Organizasyonun önerdiği ödül, bireyin potansiyel kayıplarını telafi etmelidir. $\mathrm{Bu}$ koşullar altında, farklı özendirme politikaları tasarımları, insanların davranışlarının çevre koşullarıyla karşılıklı etkileşimlerine olanak vermek üzere, bireysel davranışları etkiler (George, Jones / Understanding and managing organisational behaviour, 1999; Schneider / Organisational behaviour, 1985 ; Schneider, İnteractional psychology and organisational behaviour, 1983)( Yang, Wu, 2007 :1132).

Sonuç itibarıyla bilginin paylaşımı. 
1.Bilgiyi paylaşan taraflar arasında güven ve açılığı teminen, organizasyon yapılarının, bir şirket ya da departmanın organizasyon yapısının sessiz bilginin en iyi biçimde taşınımını desteklemesini sağlamak üzere düzenlenmesi (Sanchez, Sanchez, Ruiz, Tarrason, 2013 :391).

2.Bireysel bilginin organizasyonel bilgiyle bütünleşmesinde kökleri hem bireyde hem de organizasyonda olan engellerin(Riege, 2005) ortadan kaldırılması(Sanchez, Sanchez, Ruiz, Tarrason, $2013: 391$ ).

3.Çalışanların, bilgilerini paylaşmaya cesaretlendirilmek için, organizasyon içinde bilgi paylaşımını destekleyecek doğru bir özendirme politikasıyla desteklenmesi (Yang, Wu, 2007 :1132).

4. Çalışanların bilgilerini, atelye çalışmalarıyla firma varlıklarına ve kaynaklarına aktarılmak üzere diğer çalışanlarla paylaşmaları (Dawson, 2001) (Sanchez, Sanchez, Ruiz, Tarrason, 2013 : 395) adımlarıyla gerçekleşir.

\section{“Bilginin değerlendirilmesi " nasıl gerçekleştirilir?}

Bilginin değerlendirilmesinin temeli başarılı bir iletişimdir. Başarılı bir iletişim, diğer kişilerin ne bilip bilmediğinin ve bunun bizim bildiğimizden hangi bakımlardan farklı olduğunun izlenmesini gerektirir. Konuşma sırasında, biz, bildiğimiz ve konuşma eşlikçimizin bildiğini bildiğimiz bilginin belleklerden yapılan sunuşlarını depolarız. Bu ortak bilinen bilgiye, ortak zemin denir. İletişimin başarılı olabilmesi için, bizim bilip, eşlikçimizin bilmediğinden ortak zeminin ne olduğunu çıkarmalıyız (Clark, 1992). Günlük dil bu çıkarıma dayanır. Örneğin, dilimizi, iletişim eşlikçimizle ne kadar ortak zeminimiz olduğuna bağlı olarak, daha fazla bilgi sağlamaya yönelik (çalışma arkadaşımıza: en sevdiğim halam Annie burada) ya da daha az bilgi sağlamaya yönelik olarak ( erkek kardeşime: Annie burada) düzenleriz (Brennan \& Clark, 1996 ; Wilkes-Gibbs \& Clark, 1992). Kritik olan şudur ki, biriyle ortak zemin olan bir başkasıyla olmayabilir. Bu nedenle ortak zemin belirli eşlikçilerle bağlantılı olarak bellekte tutulur (Yoon, Duff ve Schmidt, $2017: 164,165)$.

Sessiz bilgi, bilinçaltına yerleşiktir ve bu nedenle çabucak anlaşılmaya hazır değildir. Bu bilginin diğerlerine taşınımı yazarak ya da söyleyerek kolayca gerçekleşmez (Fugate et Al.,2011). Sessiz bilginin etkin biçimde taşınımı, katılımcılar arasında düzenli ortak etkileşim ve güven gerektirir. Açık bilgi ise anlaşılan, el değiştirebilen ve depolanabilen bir bilgidir. Bu bilginin ise paylaşılması yeterlidir(Yang, Yu, Liu, Rui, 2016 :303,304).

Bireysel düzeyde bilginin taşınımı, aynı ya da ilgili işlerin yapıldığı birlikte çalışılan işçilerle yakın çalışıldığında gerçekleşir. Bireylerin çalışma arkadaşlarında birikmiş olan bilgiyi kullanma yeteneği, organizasyon içinde bilginin taşınma oranını arttırmanın bir aracı olarak tanımlanmıştır. Bu alanda yapılmış çeşitli araştırmalar, hepsi sırayla farklı mekanizmalara dayanan birlikte çalışmanın performansı neden arttırdığıyla ilgili çok sayıda açıklama sağlar. Bunlardan biri işçilerin etkinliklerini koordine etme yeteneğidir. Grup dinamikleri çalışıldığında, "kimin neyi bildiği”ni bilmenin önemine dikkat çekilmiştir. Faraj ve Sproull (2000), Larson, Christensen, Abbott ve Franz(1996), Lewis(2003), Moreland, Argote, ve Krishnan(1996) ve Wegner(1986,1995) birlikte çalışma deneyimine sahip bireylerden oluşan takımların daha doğru olduğuna ve bir takımda kimin ne bildiğine dair bir ortak paylaşılan duyguya sahip olduklarına işaret etmişlerdir. Paylaşılan iş deneyimi konusunda çalışan araştırmacılar, iletişim içinde olan eşlikçilerin öğrenmesi ve iletişimlerinin nasıl yönetileceğinin önemine vurgu yapmışlardır. Uzzi(1996), çoklu bilgi değişiminin takım güveni ihtimalini arttırdığını ifade eder. Uzzi ve Lanchester(2003), güvenin de özel bilginin 
değişimini nasıl desteklediğini tartışarak, bu fikri genişletir. Birlikte çalışma deneyiminin koordinasyonu geliştirdiğine dair çeşitli açıklamalar, birinin diğerini tamamlamasına yol açar. "Kimin neyi bildiği" ni bilmek, takım içinde rol ve sorumlulukları tanımlamada ve her role en yeterli kişiyi atamada kritik önemdedir. Yine de bu, etkili bir koordinasyonun yarısıdır. Diğer yarısı, kişilerin birbirleriyle etkileşirken belirli rolleri ne kadar iyi yerine getireceklerini çoğaltan, ilişkiye özel teşvik edici gelişmeyi başlatır. (Nembhard, Bentefouet, 2015 :176). Bireyler, öğrendiklerini grupla paylaşır, birlikte anlar ve bir grup kabulüne ulaşırlar (Kabiri, 2006)(Saadat, Saadat, 2016 :222). Bilgi akışı, uygulama toplulukları, bilgi akış ağları ve iş birliği içinde öğrenme kavramları, "bilginin tartışılması, değerlendirilmesi ve bilgide ortaklaşma”"nın uygulanması sürecini anlamamızda son derecede yararlıdır. Kirschnera ve Laib’e (2007) göre, bir uygulama topluluğu, sürece katılan kişilerin ortak ilgilerinin bulunduğu ve belirli bir süre boyunca aynı ilgilere sahip diğer kişilerle işbirliğine istekli olduğu için gerçekleşen sosyal öğrenmenin ortaya çıktığı bir süreçtir. Bir başka bakış itibarıyla, uygulama toplulukları, yaptıkları bir şeyle ilgili olarak ilgi ya da tutkularını paylaşan ve düzenli olarak etkileşerek nasıl daha iyi yapabileceklerini öğrenen insan topluluklarıdır (Wenger, Mcdermott \& Snyder, 2002). Uygulama toplulukları üyelerinin işbirliği sonuçları, fikirler, çözüm bulmalar, bir bilgi ambarı inşa etme ve her üyenin yeterliliğini değiştirmedir. Dahası, pek çok endüstri sektöründe uygulama toplulukları performans arttırmanın anahtarı olarak kabul edilirler (Abel, 2008). Etkili bir işbirliği içinde öğrenme inşa etme işinin, iki alt problemi vardır(Long \& Qing-hong, 2014) :

-Bir işbirliği içinde öğrenme ağı için kullanıcı modeli inşa etmek için uygun özelliklerin nasıl seçilip niceleneceği.

-Öğrenme hedeflerine ulaşabilmeleri için kullanıcıları optimal takımlara nasıl bölüneceği.

Araştırma, işçilerin benzersiz bir grup düzenleme davranışına ihtiyaçları olduğunu gösteriyor çünkü ortak zeminin paylaşımı diğer grup üyeleriyle etkili bir işbirliği için mutlaktır(Kwon et al., 2014). Bu çerçevede,

-İşbirliği içinde küçük ve yatay takımların oluşturulması

-Kimin neyi bildiğinin anlaşılması

-Takım içinde rol ve sorumlulukların tanımlanması

-İşbirliği içindeki grup üyelerinin derinlikli konuşmalar yaparak, çoklu bakışlar ortaya koymaları ve güvenilir tartışmalar ortaya çıkarmaları sonucunda, bilginin tartışılması, değerlendirilmesi ve bilgide ortaklaşma gerçekleşir.

\section{"Ortaklaşılan bilginin sürece katılması" nasıl gerçekleştirilir?}

Organizasyonel öğrenme, bir firmanın yeni bilgiyi anladığı, dönüştürdüğü ve muhafaza ettiği ve sonra organizasyonel etkinliklerini geliştirmekte kullandığı bir süreçtir (Grant, 1996; Huber, 1991). Organizasyonda ve stratejik yönetimde bulunan çoğu araştırmacı organizasyonel öğrenmenin yeni bilgi ve becerilerin elde edilmesi ve uygulanması olduğu konusunda hemfikirdir (Cohen \& Levinthal, 1990 ; Muthusamy \& White, 2005 ). (Shu-Mi Yang, Shih-Chieh Fang, Shyh-Rong Fang, Chia-Hui Chou (2014), s:347).

Marquardt'a göre organizasyon bağlamında, uyarlanmalı öğrenme sürecinde, bir organizasyon önceden belirlenmiş bir amaca ulaşmak için ilerler, bunun bazı iç ve dış sonuçları olur. Sonuç, amaçlara uygunluk çerçevesinde analiz edilir ve organizasyon yeni bir 
eylem yapar ya da sonuca göre bir önceki eylemi düzeltir (Saadat, Saadat, 2016 :222). Nonaka ve Takochi (1995), organizasyonel öğrenmeyi, organizasyonun etkinlik alanına uygun bilgi üzerindeki hakimiyeti olarak tanımlarlar. Onlara göre bilgi (organizasyonel öğrenme süreci) üzerindeki hakimiyet süreci üç adımdan oluşur :

-Bilgiyi elde etme (yararlı bilginin tanımlanması ve toplanması)

-Bilgiyi kullanma (bilginin uygulamada kullanılması)

-Bilginin taşınımı (organizasyon içinde dağıtımı ve yayınlanması)(Allameh \& Moghaddami, 2010) (Saadat, Saadat, 2016 :223).

Yöneticiler, organizasyonlarına nüfuz edebilecek bilginin özellikleri ve yöntemlerine yukarıdan bakmalı, operasyonel bir anlam çıkarmalı, kişilerin bilgiyi elde etme ve sorunları çözme yollarını bilmeli, performansı ve işi geliştirmek üzere süreçlere, yapılara ve organizasyonel etkinliklere yön vermek için bilgiyi nasıl kullanacağını bilmelidir (Allameh \& Moghaddami, 2010) (Saadat, Saadat, 2016 :224). Tiwana (The knowledge management toolkit : Practical techniques for building a knowledge management system, 2000) bilgi yönetimi ile ilgili uygulamalı ve sonuç odaklı bir yaklaşım geliştirmiştir : "Bilgi, çerçevesi belli bir deneyim, değerler, içerik bilgisi ve ayakları yere basan sezginin, yeni deneyimler ve bilgi geliştirilmesi ve bir araya getirilmesi için bir çevre ve çerçeve sağlayan karışımıdır." Bu, bilenlerin kafasında ortaya çıkar ve uygulanır. Organizasyonlarda, çoğunlukla, yalnızca belge ve belleklerde değil keza organizasyon rutinlerinde, süreçlerinde, uygulamalarında ve ilkelerinde içselleştirilir. (Schombacher, Lahorte, Vistisen, Versluis, Martins, Meyer, Patras, Bardella, Roux, Kreuter, Scott, 2016 :2). Kaynaklarda, organizasyonel öğrenmeye süreç odaklı yaklaşım iyi tanınır. Argyris ve Schon (1978), öğrenmeyi, hataların tespiti ve düzeltilmesi süreci olarak tanımlar. Organizasyonel öğrenmeye yönelik bu yaklaşımın kökleri, John Dewey'in deneyimden öğrenme kuramındadır. Dewey, öğrenmeyi, deneyimin sürekli bir yeniden düzenlenmesi ve yeniden yapılandırılması; tekrarlanan bir planlama süreci; eylemlerin uygulanması, yansıtılması ve uyarlanması olarak tanımlamıştır (Elkjaer, 1999). İş takımlarında öğrenme davranışı itibarıyla, çekicilik bu tür etkinlikler üzerindedir. Yani takım üyelerinin yaratarak, paylaşarak ve yararlanarak uyguladıkları bu tür etkinlikler üzerindedir (Argote, 1999). Öğrenme etkinliklerine örnekler (Edmondson, 1999; Preskill \& Torres, 1999) : geri bildirim arama, yardım isteme, sorular sorma, hatalar hakkında konuşma, bilgi paylaşma, tartışma, deneme, etkinlik planlama ve uygulamadır (Babnik, Sirca, Dermol, 2013 :180). Bu çerçevede ortaklaşılan bilginin uygulanması ve sürece katılması,

-Ortaklaşılan bilginin amaca uygunluk çerçevesinde nasıl kullanılacağın atelyelerde değerlendirilmesi

-Bu bilginin uygulamasına yönelik olarak etkinliklerin atölyelerde planlanması

-Bilginin uygulanması

Adımlarıyla gerçekleştirilir.

\section{"Sürecin her adımı itibarıyla kayıt altına alınması" nasıl gerçekleştirilir?}

Bilgi, operasyonel rutinler çerçevesinde paylaşılıp içselleştirildikten sonra, bireyler ve organizasyonlar bunu, yönergeler gibi uygun bir alan üzerinden organizasyonel hafızaya almalıdır (bilgi tutundurma ya da depolama gibi)(Zollo \& Winter, 2002). Dahası, 
organizasyonlarda dinamik yeteneklerin biçimlendirilmesine dair kaynaklar üzerine yaptıkları kapsamlı araştırmalarda Zollo ve Winter, organizasyonel belleğin bu sürecinin, organizasyonel bilginin etkin bir yayılmasına da yol açtı̆̆ını söyler. Bu bilgi, önceki bireysel deneyim, mevcut iç rutinler, yeni işletme rutinleri ve organizasyonun operasyonlarına dair herhangi bilgilerden oluşur. Hickins'e (2000) göre, insanlar bilgi havuzuna bilgi ekleme konusunda zaman harcamaya isteksizdirler. Ve herkes bilir ki, veri tabanı ihtiva ettiği bilgi kadar değerlidir. Tutundurma ve depolama önemli bir süreçtir. Bilgi yönetimi, bazı çalışanlar özellikle derleme, planlama ve bilgi ağları ve teknoloji havuzlarının organize edilmesinden sorumlu tutulmadıkça başarılı olamaz. Gerçekte, bilgi, konuşmalar ve onların günlük uygulamalarda kullanımıyla taşınabilir. Ancak, insanların açık kayıtları organizasyonel sistemin bir parçası olarak kaydetmemeleri mümkündür. Çalışanlar gelip gittikçe ve liderlik ve patronluk değiştikçe bilgi dağılabilir. Buna bir kanıt, "organizasyonlar deneyimlerden rastgele öğrenirler ve nadiren organizasyonel bellekte içselleşmiş kullanılabilir bir bilgiye dönüştürülebilir yollarla elde tutarlar" diyen Wagner(2003) tarafından sağlanmıştır. Argote'nin (1999) organizasyonel öğrenme üzerine çalışması, bilginin üç farklı bellek sisteminde tutulduğunu gösterir:

-bireysel bellek,

-bir organizasyonun bilgi teknolojileri ve araçları

-organizasyonun yapıları ve günlük tekrarlanan uygulamaları.

Çalışan giriş çıkışı üst düzeyde olursa ve bireysel bilgi tutulamadığında bunların üçü de zarar görür (Yang, 2007 :348). Bilgiyi yaşamsal bir kaynak olarak niteleyerek, organizasyonlar, bugün ve gelecek için bilginin korunmasının değerini fark ederler. Bilginin korunması (yaygın olarak "organizasyonel bellek " diye nitelenir), ortaya çıkarılma ve yeniden kullanma itibarıyla bilgi yönetiminin ana yapı taşı gibidir. Organizasyon üyeleri arasında paylaşılan bilgi, bir kişinin beyninde kalandan daha değerlidir. Dahası, böyle taşınan bir bilginin, ona ilk sahip olanla yeniden iletişim kurmadan da gelecek kullanımları için organizasyon üyelerinin yararlanabilsin diye bir arşivde depolanmalı ya da tutundurulmalıdır. Bir konu hesaba katılmalıdır ki, bilgi arşivine organizasyonun tüm bilgileri kaydedilmemelidir. Çünkü eğer bilginin ilgisiz bölümleri de yüklenirse, arşiv bir nevi çöple dolacaktır. Bu yüzden, güncel, uygun ve doğru diye kabul edilen bilgi, organizasyona daha fazla yarar sağlamasını teminen arşivlere kaydedilmeli ve oradan yeniden alınabilir olmalıdır. Gerçekte, organizasyonda bilgi, çoklu yerlerde ya da muhafaza alanlarında durur (J.P.Walsh \& G.R.Ungson, 1991 ; B.Lewitt \& J.C.March, 1988 ; W.R.Starbuck, 1992). Örneğin Walsh ve Ungson, "kayıt yerleri ve tutundurma olanakları" terimini, bilginin kayıt edilebileceği beş iç yer (bireyler, kültür, dönüşümler, yapılar ve ekoloji) ve bilginin ortaya çıkarıldığı ve tutundurulduğu dış çevre için kullanır. Connelly ve Kelloway (2001) ve Argote ve Ingram (2000)'a göre bilginin kayıt altına alınması, karşılıklı bilgi değişim süreciyle bütünleşik olmalıdır. Bilgi sistemleri, bilgi yönetimi, organizasyonel öğrenme ve strateji kaynaklarından yola çıkarak, bilgi paylaşımı, paylaşım mekanizmaları marifetiyle paylaşandan kullanana bilginin dışsallaştırılması ve içselleştirilmesi ile sınırlı tutulmamalı keza kayıt alanları üzerinden de olmalı. Bu süreçle ilgili olarak üç bileşenden söz edebiliriz.

-Oyuncular

-Arşivler

-Mekanizmalar 
Oyuncular, bilginin taşınım sürecinde paylaşan ve kullanan olarak en az iki kişi olması gereken, organizasyonun insan unsurlarıdır. İkilinin herhangi biri bilgi paylaşımını başlatabilir. Kullanıcı ihtiyaç duyduğu bilgiyi organizasyondan ya da organizasyonun bir başka üyesinden talep edebilir ya da bilgiye sahip olan kişi gönüllü olarak organizasyonun diğer üyeleriyle paylaşabilir.

Arşivler, organizasyondaki bilginin bulunduğu çoklu yerler ya da tutundurma noktaları anlamina gelir. Bir birey bilgi kayıt etmenin en etkin yolu ise de, bir organizasyonun hiç bir özel üyesi bir organizasyon belleğinin tek kayıt noktası değildir. O nedenle, şirket ölçeğinde, organizasyonun her üyesinin bilgisini gelecekteki kullanımlar için düzgün ve kodlanmış biçimde kayıt altına alacağı bir arşiv gereklidir. Organizasyonel belleğin böyle bir arşivi, bilgi kullanıcısının, bilgi paylaşana yaklaşmadan önce daha önce paylaştı̆̆ı bilgiyi netleştirmeden bir ön çalışma yapmasına olanak verir. Dahası, bu, bilgi paylaşanların, bilgi arayanlar tarafından işlerinin orta yerinde bölünmemelerini de sağlar. Arşiv, bilgi paylaşma sürecinin her iki tarafı için bir kazan-kazan durumu ortaya koyar.

Mekanizmalar, üzerinden sessiz ya da açık bilginin taşındığı alanlardır. Bugünkü durumda öyle anlaşılıyor ki, bilgi taşınımında, Hansen(1999)'in kişiselleştirme stratejisi ve kodlama stratejisi dediği kişiselleştirilmiş ve kişiselleştirilmemiş mekanizmalar kullanılıyor. Hansen(1999), kodlama stratejisinde bilgi açıkça ifade edilmiş ve organizasyon üyesinin ulaşabileceği ve kolaylıkla kullanabileceği veri tabanlarına kaydedilmişken, kişiselleştirme stratejisinde bilginin sahip olan kişiye sıkı bir biçimde bağlı ve esas itibarıyla kişiden kişiye etkileşimle paylaşılabildiği bir yaklaşım olduğunu ileri sürer.

Sajjad M. Jasimuddin, bir organizasyonda bilginin taşınımında iki mekanizmanın rolüyle ilgili olarak araştırmacılar arasında ciddi ayrımlar olsa da, iki mekanizma arasında karşılıklı etkileşimi tanıyan ortak bir stratejiyi öneriyor (Jasimuddin, 2005 : 39, 40, 42, 43). Bu bakış1 yansıtmak üzere, bilgi ve iletişim teknolojileri, sessiz ve açık bilginin paylaşılmasının ve organizasyonun açık bilgisinin kayıt altına alınmasının güçlü bir yolu olabilecek bireylerin ağlarına olanak verir. Web tabanlı teknoloji, konumlarından bağımsız olarak bilgi paylaşmak için organizasyon üyeleri arasında iletişim için güçlü bir karşılıklı etkileşimli iletişim ortamı sağlayabilir. Bu, kez, eşzamanlı olarak paylaşılan bilginin kayıt altına alınmasına da olanak verir. Bilgi paylaşımının ve bilginin kayıt altına alınmasının önerilen bütünleşik yaklaşımı karşılıklı etkileşime dayanan, sürekli ve dinamik bir süreçtir ve durağan bir bilgi gövdesine, belirli bir iletişim mekanizmasına ya da bilginin tek boyutlu akışına dayandırılamaz (Jasimuddin, 2005 :43). Bu çerçevede bilginin kayıt al tına alınması şu adımlarla gerçekleştirilir:

-Bilgi paylaşımına konu süreçle ilgili bilgilerin kayıt altına alınacağı bir bilgi\&iletişim teknolojileri alanının (örneğin bir web tabanlı blog) belirlenmesi

-Üzerinde ortaklaşılan bilginin kayıt altına alınmasını gerçekleştirmek üzere grup üyeleri arasında görevlendirme yapılması

-Bu bilgi/bilgilere erişim için kişilerin yetkilendirilmesi

-Bilginin yetkilendirilen çalışanlar marifetiyle belirlenen kayıt alanına (örneğin web tabanlı bir blog) kayıt altına alınması. 


\section{Sonuç}

Küresel ve yerel planda sürekli sertleşerek yükselen rekabet, şirketleri de sürekli biçimde performans iyileştirme süreçlerine zorlamaktadır. Organizasyonel öğrenme bu tür süreçlerin en etkili olanlarından biridir. Bir yandan adımların uygulanacağı süreçlerde mevzi iyileşmelere yol açacak, diğer yandan, şirket, çalışanlar ve üretim süreci/süreçleri konusunda yaratacağı farkındalık, önemli stratejik kararlar için esin kaynağı olacaktır.

Başlica,

1. Organizasyonel öğrenme sürecinin uygulanacağı bir organizasyon ve/veya organizasyon departmanınin belirlenmesi.

2. Söz konusu organizasyonun yatırımcısı-yöneticisi ile organizasyon ya da departmana organizasyonel öğrenme sürecinin adımlarının ve uygulanmasının anlatılması.

3. Söz konusu organizasyon ya da departmandan, süreci yönetecek bir öğrenen takımın gönüllülük esasıyla seçilmesi.

4. Süreç boyunca tartş̧maların ve üretilen-paylaşılan-belirlenen-uygulanan bilginin kayıt altına alınacağı bir alan (örneğin bir web blog) belirlenmesi-tasarlanması ve giriş için öğrenen takım üyelerinin yetkilendirilmesi.

5. Bilginin ortaya çıarılması, bilginin paylaşılması, bilginin değerlendirilmesi, bilginin sürece/süreçlere katılması ve kayıt altına alınması adımlarının çalışmamızda önerildiği çerçevede uygulamaya başlanması.

6. Belirlenen süre boyunca ve sonunda uygulamanın performansa yansımasının değerlendirilmesi.

adımlarıyla uygulanabilecek olan bu süreç, şirketin performans iyileştirme yolculuğunda önemli bir eşik olacaktır. Hiç kuşkusuz, genel itibarıyla öğrenme ve çalışmamız itibarıyla da organizasyonel öğrenme, sürekli ve aralıksız bir etkinlik, bir haldir. Organizasyonel öğrenme sürecinin adımlarını bir arada görünür hale getirmeyi ve bu adımların nasıl uygulanacağına dair bir öneriyi amaçlayan çalışmamız, bütünü itibarıyla bugüne kadar yapılmış çalışmalara ve yayınlara dayanmaktadır. Yapılacak uygulamalar tarafından da doğrulanacağını ve çıkacak sonuçların da katkılarıyla daha da zenginleşeceğini değerlendiriyoruz.

\section{Kaynakça}

Alaarj, Mohamed, Bustamam, 2016, Mediating Role of Trust on the Effects of Knowledge Management Capabilities on Organisational Performance, Procedia-Social and Behavioral Sciences :730,731, 733 .

Aponte, Zapata, 2013, A model of organisational learning in practice, Estudios Gerenciales, :443.

Babnik, Sirca, Dermol, 2014, Individuals learning in work teams: Support to knowledge management initiatives and an important source of organisational learning, Procedia-Social and Behavioral Sciences : 180 .

Brix, 2017, Exploring knowledge creating process as a source of organisational learning: A longitudinal case study of a public innovation Project, Scandinavian Journal of Management, : 115. 
Dasi, Pedersen, Gooderham, Elter, Hildrum, 2017, The effect of organisational separation on individuals' knowledge sharing in MNCs, Journal of World Business : 435.

Jasimuddin, 2005, An Integration of Knowledge Transfer and Knowledge Storage: An Holistic Approach, GESTS International Trans. Computer Science and Engineering :39,40,42,43.

Loebbecke, Van Fenema, Powell, 2016, Managing inter-organisational knowledge sharing, Journal of Strategic Information Systems,

Nembhard, Bentefouet, 2014, Selection, grouping, and assignment polices with learning-by-doing and knowledge transfer, Computers \& Industrial Engineering : 176.

Nesheim, Hunskaar, 2015, When employees and external consultants work together on projects: Challenges of knowledge sharing, International Journal of Project Management :1418.

Nieves, Haller, 2014, Building dynamic capabilities through knowledge resources, Tourism Management : 226.

Razak, Pangil, Lazim, Zin, Yunus, Asnawi, 2016, Theories of Knowledge Sharing Behaviour in Business Strategy, Procedia Economics and Finance : 547.

Saadat, Saadat, 2016, Organisational Learning as a Key Role of Organisational Success, ProcediaSocial and Behavioral Sciences : 221, 222, 223, 224, 225.

Sanchez, Sanchez, Ruiz, Tarrason, 2013, Knowledge Creating and Sharing Corporate Culture Framework, Procedia- Social and behavioral Sciences : 390,391,394,395.

Schombacher, Lahorte, Vistisen, Versluis, Martins, Meyer, Patras, Bardella, Roux, Kreuter, Scott, 2016, Continuous Knowledge Transfer - A pragmatic approach to knowledge sharing in the European Patent Office, World Patent Information :2.

Senge, 2013, Beşinci Disiplin / Öğrenen Organizasyon sanatı ve Uygulaması, Yapı Kredi Yayınları, 18nci Baskı, 2006.

Shin, Picken, Dess, 2017, Revisiting the learning organisation: How to create it, ScienceDirect : 49,50 .

Spector, Davidsen, 2006, How can organisational learning be modeled and measured ?, Evaluation and Program Planning : 66.

Sujatha, Krishnaveni, 2018, Knowledge creating ba as a determinant of work performance of employees: An emprical analysis among pump manufacturing firms in South India, Asia Pasific Management Review :46,47,49.

Yang, 2007, Individual attitudes and organisational knowledge sharing, ScienceDirect, :347,348.

Yang, Wu, 2007, Knowledge sharing in an organisation, ScienceDirect : 1132,1134.

Yang, Yu, Liu, Rui, 2016, Improving learning alliance performance for manufacturers: Does knowledge sharing matter ?, Int.J. Production Economics : 303,304

Yoon, Duff, Schmidt, 2017, Learning and using knowledge about what other people do and don't know despite amnesia, ScienceDirect :164,165. 